\title{
PALPIMANID SPIDERS FROM GUYANA: NEW SPECIES OF THE GENERA FERNANDEZINA AND OTIOTHOPS (ARANEAE, PALPIMANIDAE, OTIOTHOPINAE)
}

Cristian J. Grismado ${ }^{1}$

\begin{abstract}
Two new species of the spider family Palpimanidae from Guyana are described: Fernandezina takutu, the first species of this genus known from this country and Otiothops giralunas, that seems to be the sister species of $O$. goloboffi Grismado, 1996 from northwestern Argentina.
\end{abstract}

KEYWORDS. Fernandezina, Otiothops, Palpimanidae, Taxonomy, Neotropical.

\section{INTRODUCTION}

The spider subfamily Otiothopinae (Palpimanidae) is known only from Central and South America, and currently comprises four genera: Otiothops Mac Leay, 1839, Anisaedus Simon, 1893, Fernandezina Birabén, 1951 and Notiothops Platnick, Grismado \& Ramírez, 1999, the latter endemic to Chile. The group was revised by Platnick (1975) and new data and taxa were provided recently (PLATNicK et al., 1999).

Only two species are known from Guyana: Otiothops oblongus Simon, 1891 and $O$. whitticki Mello-Leitão, 1940 (Platnick, 1975). Now I had the possibility to examine some specimens recently collected in this country, founding a male (along several immatures) of a new Otiothops, and a male of a new Fernandezina, the first one known from Guyana. The habitat of these spiders is the leaf litter of the tropical rainforest near the margin of Essequibo River, in a zone not floodable (Gustavo Hormiga, pers. comm.).

Fernandezina contains only eigth species (from Argentina, Brazil and Peru) described by Birabén (1951), Platnick (1975), Ramírez \& Grismado (1996) and Platnick et al. (1999), and is recognized by the unexpanded femur I, the tarsus I nearly as long as tibia I, and the enlarged abdominal scutum of males, covering at least half of dorsum.

Otiothops is a more speciose genus and has the widest geographic distribution in the subfamily (more than thirty species, from Caribbean Islands to Argentina, PLATNICK, 1997), and is diagnosed by the presence of claw tufts and closely spaced posterior median eyes (PlatnICK, 1975). The new Otiothops here described shares with O. goloboffi,

$\overline{1 .}$ Museo Argentino de Ciencias Naturales "Bernardino Rivadavia", División Aracnología, Av. Angel Gallardo 470 C1405DJR, Buenos Aires, Argentina. (grismado_macn@yahoo.com.ar/grismado@muanbe.gov.ar) 
described by Grismado (1996) from Salta, northwestern Argentina, the flattened and sinuous embolus with a longitudinal traslucent area restricted to the distal half are not present in other congeners nor in other known otiothopine genera, it seems to be a synapomorphy of these two species. The disparate geographical distribution of these (probably) sister species may reflects the insufficient collection fieldwork in extensive areas of South America, at least concerning on litter fauna.

Specimens are deposited in the National Museum of Natural History, Smithsonian Institution (USNM, Jonathan Coddington). The format of descriptions follows PLATNICK (1975). All measurements are in millimeters.

\section{Fernandezina takutu sp. nov.}

(Figs. 1-4)

Type. Male holotype from Guyana, Upper Takutu-Upper Essequibo Reg. $4.42 \mathrm{~km} \mathrm{~S}$ Gunn's strip, bank of Essequibo River (1³6’45.7’N, 58³8'14.6”'W) 240 m, 6-15 Jul. 1999, J. A. Coddington, G. Hormiga, J. Miller, I. Agnarsson \& M. Kunter col. (USNM).

Etymology. The specific name is a noun in apposition taken from the type locality.

Diagnosis. The male of Fernandezina takutu differs from all other congeners by the shape of the embolus, sinuous and striated (figs. 2-4) without any flange or ledge.

Description. Total length 2.92. Carapace 1.24 long, 0.96 wide (at second leg). First leg: femur 1.40 long, 0.32 heigh; patella 1.08 long; tibia 0.82 long; metatarsus 0.44 long; tarsus 0.52 long. Abdomen: 1.50 long; dorsal scutum: 0.80 long. Posterior median eyes separated by nearly their diameter (fig. 1). All sclerotized prosomal integuments orange. Legs yellowish (except all femora, tibiae I and metatarsi I, orange). Unsclerotized abdomen whitish; dorsal scutum orange brown with irregular posterior margin (fig. 1). Sides of scutum extending ventrally to point halfway between sides and midline. Palp (figs. 2-4): tibia globose, larger than bulb; embolus striated, with proximal origin, with broad base and a longitudinal groove in prolateral side (fig. 2), apex laminar and truncated, slightly twisted at the end in ventral view (fig. 3).

\section{Otiothops giralunas sp. nov.}

(Figs. 5-7)

Type. Male holotype from Guyana, Upper Takutu-Upper Essequibo Reg. $4.42 \mathrm{~km} \mathrm{~S}$ Gunn's strip, bank of Essequibo River (1³6'45.7” N, 58³8'14.6”'W) 240 m, 6-15 Jul. 1999, J. A. Coddington, G. Hormiga, J. Miller, I. Agnarsson \& M. Kunter col. (USNM).

Etymology. Named from "Giralunas", the Theatre group of my wife Andrea.

Diagnosis. The palp of Otiothops giralunas resembles those of $O$. goloboffi by the sinuous, flattened embolus with a longitudinal traslucent area restricted to the distal half (TA, fig. 6), but differs by their more elongate and thin shape and by the lesser curved terminal part of sperm duct (figs. 5-7).

Description. Total length 3.64. Carapace 1.70 long, 1.24 wide (at second leg). First leg: femur 1.34 long, 0.54 heigh; patella 1.02 long; tibia 0.86 long; metatarsus 0.36 long; tarsus 0.42 long. Abdomen: 1.70 long. Posterior median eyes contiguous. All sclerotized prosomal integuments orange brown; legs I orange (except tarsus, yellowish), legs II-IV 

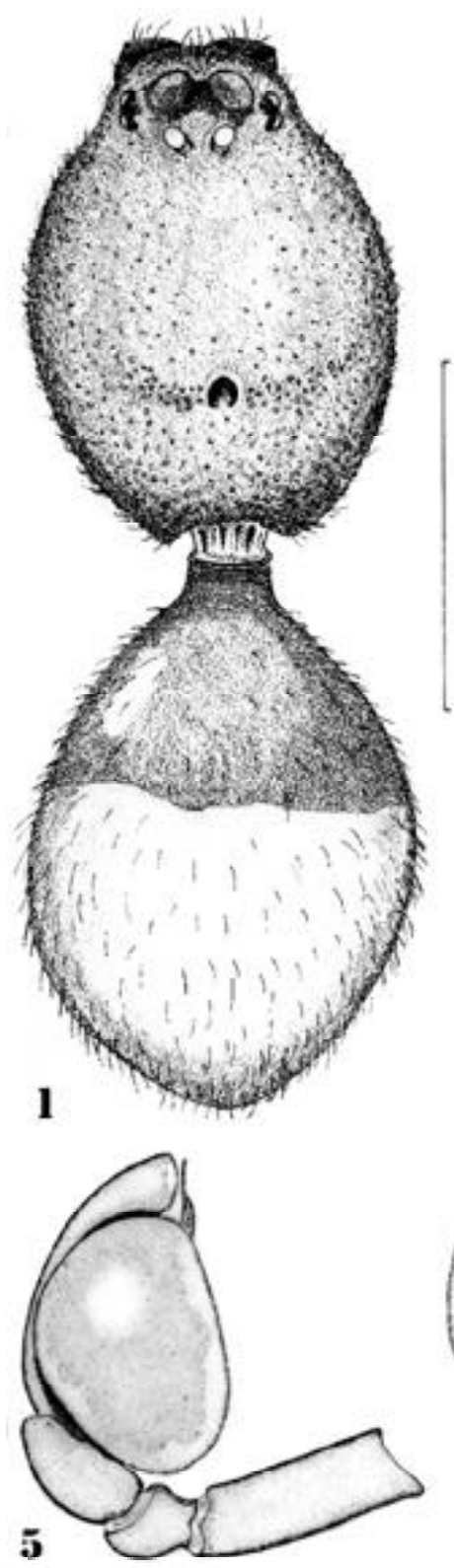
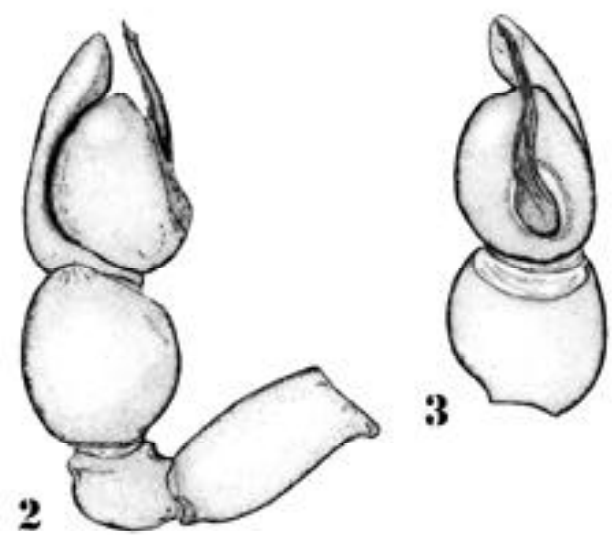

2
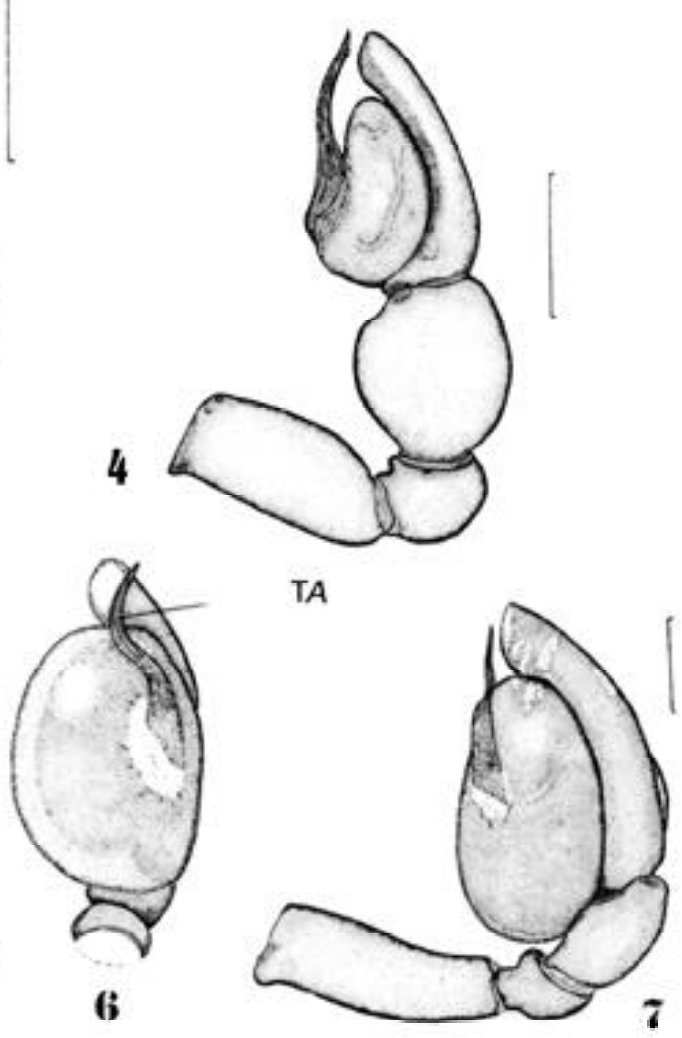

Figs. 1-7. Fernandezina takutu sp. nov. male holotype: 1, dorsal view of cephalothorax and abdomen; 2, palp, prolateral view; 3, ventral; 4, retrolateral. Otiothops giralunas sp. nov.: 5, palp, prolateral; 6, ventral; 7, retrolateral (TA, traslucent area). Scale bars: fig. 1, $1 \mathrm{~mm}$; figs. 2-4; 5-7 respectively in the same scale, $0.2 \mathrm{~mm}$. 
and palps yellowish. Abdomen: dorsum and sides violaceous brown with cream spots; ventrally, scutum orange, posteriorly to this, a wide longitudinal band light brown. Palpal bulb globose (figs. 5-7). All other characters are typical for the members of the genus.

Other material examined. Six immatures (same data as the holotype) probably belong to the same species (USNM).

Acknowledgments. Helpful comments on the draft of the manuscript were provided by Martín J. Ramírez, Norman I. Platnick (American Museum of Natural History, New York), Antonio Brescovit (Instituto Butantan, São Paulo) and an anonymous reviewer. To Jonathan Coddington, David Furth and Scott Larcher (USNM) by the loan of specimens, to Gustavo Hormiga (USNM) for comments on the type locality.

\section{REFERENCES}

Birabén, M. 1951. Fernandezina, nuevo género de Palpimanidae. Acta zool. lilloana, Tucumán, 12:545-549.

Grismado, C. J. 1996. Una nueva especie del género Otiothops Mac Leay de Argentina (Araneae, Palpimanidae). Mus. Arg. Cs. Nat. Extra, N. S., Buenos Aires, 130:1,2.

Platnick, N. I. 1975. A Revision of the palpimanid spiders of the new subfamily Otiothopinae (Araneae, Palpimanidae). Am. Mus. Novit., New York, (2562):1-32.

1997. Advances in spider taxonomy 1992-1995 with redescriptions 1940-1980. New York, New York Entomological Soc. 976p.

Platnick, N. I.; Grismado, C. J. \& Ramírez, M. J. 1999. On the genera of the spider subfamily Otiothopinae (Araneae, Palpimanidae). Am. Mus. Novit., New York, (3257):1-25.

Ramírez, M. J. \& Grismado, C. J. 1996. A new Fernandezina from Brazil (Araneae, Palpimanidae). Iheringia, Sér. Zool., Porto Alegre, (80):117-119.

Recebido em 31.10.2001; Aceito em 07.05.2002 